\title{
FDI and Growth of Service Sector in India
}

\author{
Debabrata Sutradhar*
}

\begin{abstract}
In the contemporary globalised economy, service sector attracts the major share of Foreign Direct Investment (FDI) in the world. India being a part of this phenomenon also attracts most of its FDI in the service sector. The present paper highlights the trend in FDI movement in the world in general and India in particular. Further, it reviews the FDI policy in India in the post liberalized period. The growth of FDI in services sector may be attributed to the changing pattern of global FDI and also the liberalization and globalization policies pursued by India. Since 2000, the high inflow of FDI has resulted in the growth of new services viz., financial and nonfinancial services, telecommunication, computer software and hardware, hotel and tourism, construction activities and real estate. The growth of services sector had led to the growth of export of services from India which now accounts the majority of export from the country.
\end{abstract}

Keywords: FDI, Services sector, Export, Liberalization

\section{Introduction}

The sectoral distribution of FDI inflow has been undergoing transition with structural changes taking place in different countries of the world. Previously, majority of FDI movement took place in the primary and manufacturing sector, but with economic development gaining momentum, particularly in the developing countries, service sector has acquired dominant status. As a result, the movement of FDI inflow is directed towards the service sector.

* Research Scholar, Department of Humanities and Social Sciences, National Institute of Technology, Silchar, Assam, India; debabrata.01@gmail.com 
Table 1 shows the global trend of sector-wise distribution of FDI inflow during 1990-92 and 2008-10 in developed economies, developing economies, and transition economies. During 1990-92 majority of global FDI inflow took place in the service sector followed by manufacturing and primary sectors. The share of FDI in the service sector was 54.48 percent of the total FDI inflow in the world while the share of manufacturing sector was 29.68 percent and the share of primary sector was only 8.73 percent. During 199092 , service sector dominated the movement of inward FDI both in the developed and developing economies whereas in case of the transition economies it was manufacturing sector. The industries which attracted the bulk of the inward FDI during 1990-92 in service sector are business activities, finance and trade. In manufacturing sector, most of the inward FDI took place in food and beverages, metal and metal products and in machinery and equipment.

By 2008-10, there is a marked shift in the sectoral distribution of world's inward FDI. The share of services sectors increased from 54.48 percent during 1990-92 to 63.05 percent during 2008-2010. The share of inward FDI in the developed economies has declined from 44.16 percent in 1990-92 to 39.83 percent in 2008-2010, while in the same period the share of services in the inward FDI in the developing economies has doubled from 10.20 percent to 20.40 percent. Similarly in the case of transition economies, the share of services increased from a mere 0.12 percent to 3 percent in the same period. In case of manufacturing sector, there was a decline in the inflow of inward FDI in the world from 29.68 percent during 199092 to 24.41 percent during 2008-2010. But the decline in manufacturing sector was pronounced in the developed economies and the share of manufacturing towards total FDI inflow declined to a mere 13.68 percent during 2008-2010. In the case of developing and the transition economies the trend was a reverse. The developing economies experienced marginal rise in inflow of FDI in the manufacturing sector from 8.25 percent during 1990-92 to 9.85 percent during 2008-2010. 
Table 1. Estimated world inward FDI flows, sector and industry, 1990-92 and 2008-2010

\begin{tabular}{|c|c|c|c|c|c|c|c|c|}
\hline 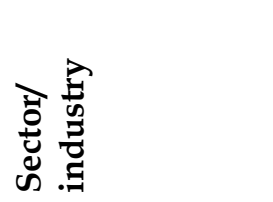 & 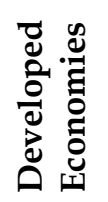 & 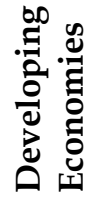 & 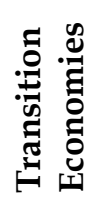 & 童 & 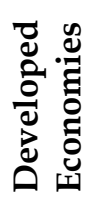 & 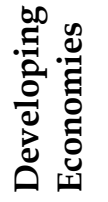 & 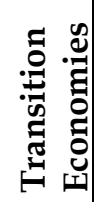 & 沝 \\
\hline & \multicolumn{4}{|c|}{$1990-92$} & \multicolumn{4}{|c|}{$2008-2010$} \\
\hline Primary & 5.81 & 2.40 & 0.52 & 8.73 & 2.97 & 4.66 & 0.95 & 8.58 \\
\hline $\begin{array}{l}\text { Mining, } \\
\text { quarrying and } \\
\text { petroleum }\end{array}$ & 5.79 & 1.99 & 0.52 & 8.30 & 2.91 & 4.29 & 0.91 & 8.12 \\
\hline Manufacturing & 21.30 & 8.23 & 0.16 & 29.68 & 13.68 & 9.85 & 0.88 & 24.41 \\
\hline $\begin{array}{l}\text { Food, beverages } \\
\text { and tobacco }\end{array}$ & 2.84 & 0.84 & 0.03 & 3.71 & 4.01 & 0.80 & 0.12 & 4.92 \\
\hline $\begin{array}{l}\text { Chemicals and } \\
\text { chemical } \\
\text { products }\end{array}$ & 3.43 & 0.92 & 0.01 & 4.35 & 3.11 & 1.00 & 0.03 & 4.15 \\
\hline $\begin{array}{l}\text { Metal and metal } \\
\text { products }\end{array}$ & 1.45 & 0.33 & 0.03 & 1.81 & 0.84 & 0.79 & 0.29 & 1.92 \\
\hline $\begin{array}{l}\text { Machinery and } \\
\text { equipment }\end{array}$ & 2.46 & 0.32 & 0.00 & 2.78 & 0.57 & 0.51 & 0.02 & 1.10 \\
\hline $\begin{array}{l}\text { Electrical and } \\
\text { electronic } \\
\text { equipment }\end{array}$ & 0.61 & 0.47 & 0.02 & 1.10 & 0.85 & 1.02 & 0.04 & 1.91 \\
\hline $\begin{array}{l}\text { Motor vehicles } \\
\text { and transport } \\
\text { equipment }\end{array}$ & 1.51 & 0.36 & 0.00 & 1.88 & 1.28 & 0.44 & 0.09 & 1.82 \\
\hline $\begin{array}{l}\text { Unspecified } \\
\text { secondary }\end{array}$ & 5.31 & 3.87 & 0.06 & 9.24 & 1.02 & 3.80 & 0.07 & 4.90 \\
\hline Services & 44.16 & 10.20 & 0.12 & 54.48 & 39.83 & 20.20 & 3.03 & 63.05 \\
\hline $\begin{array}{l}\text { Business } \\
\text { activities }\end{array}$ & 9.73 & 10.70 & 0.07 & 12.23 & 9.39 & 8.26 & 1.22 & 18.87 \\
\hline Finance & 14.65 & 6.47 & 0.01 & 16.12 & 18.85 & 4.17 & 0.52 & 23.53 \\
\hline Trade & 9.52 & 6.22 & 0.01 & 10.94 & 4.53 & 2.38 & 0.59 & 7.49 \\
\hline $\begin{array}{l}\text { Transport, } \\
\text { storage and } \\
\text { communications }\end{array}$ & 2.04 & 3.74 & 0.01 & 2.90 & 1.53 & 1.77 & 0.22 & 3.52 \\
\hline
\end{tabular}




\begin{tabular}{|c|c|c|c|c|c|c|c|c|}
\hline 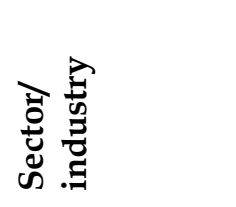 & 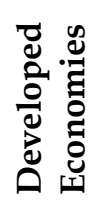 & 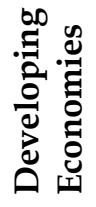 & 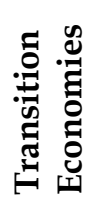 & 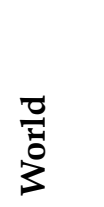 & 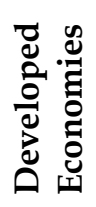 & 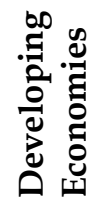 & 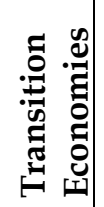 & $\begin{array}{l}\bar{T} \\
\overline{3} \\
3\end{array}$ \\
\hline & \multicolumn{4}{|c|}{ 1990-92 } & \multicolumn{4}{|c|}{ 2008-2010 } \\
\hline $\begin{array}{l}\text { Electricity, gas } \\
\text { and water }\end{array}$ & 0.38 & 7.17 & 0.00 & 2.00 & 2.41 & 0.86 & 0.13 & 3.40 \\
\hline Construction & 0.16 & 1.77 & 0.01 & 0.57 & 0.28 & 1.27 & 0.12 & 1.67 \\
\hline Unspecified & 5.18 & 8.03 & 0.07 & 7.07 & 2.69 & 0.51 & $\begin{array}{r}- \\
0.02\end{array}$ & 3.18 \\
\hline Total & 76.49 & 22.64 & 0.87 & 100 & 59.93 & 35.21 & 4.86 & 100 \\
\hline
\end{tabular}

Source: Compiled by the researcher, UNCTAD stat database[1] In case of primary sector, there is a mixed trend in the global distribution of FDI among different economies. As far as the global inward FDI is concerned, there was no major change, but the share of inward FDI in the developed economies declined from 5.81 percent during 1990-92 to 2.97 percent during 2008-2010. But in the same period the inward FDI in the developing economies has increased by more than two times from 1.9 percent during 1990-92 to 4.29 percent during 2008-10. The growth of inward FDI in primary sector was also experienced in the transition economies from 0.52 in 1990-92 to 0.95 in 2008-10.

Within the manufacturing sub-sector which received majority of FDI during 2008-10 are food, beverages and tobacco, and chemical and chemical product, metal and metal products, electrical and electronic equipments, motor vehicles and transport equipments. Similarly, the service sub-sectors which are receiving major share of FDI in the world in the last two decades are business activities, finance, trade, transport and communication and construction activities.

From table 1, we may conclude that though the share of services towards global total inward FDI has been increasing, the share of manufacturing sector is decreasing. It is important to note that the share of inward moving FDI in manufacturing is increasing in the developing economies. This may be due to the fact that most of the developing economies are growing and require heavy investments in manufacturing, especially in foreign technology and management. Given this global phenomenon of inward FDI movement, I would like to see if India's FDI inflow also follows this trend or not. 


\section{Sectoral Distribution of FDI inflow in India before Economic Reform of 1991}

Foreign investment in a country is determined by its foreign investment policy. The foreign investment policy in the pre-reform period (1947 to 1990) was very restrictive. However, with the initiation of economic reforms and consequent change in foreign investment policy, FDI inflow started to increase. The sector-wise distribution of FDI in India has been different at different time periods. It has been noted that over time, foreign investment in the form technical collaboration or technological transfer is being preferred over financial collaboration. The technical collaboration helps to acquire cutting edge technology much required by developing countries like India. Needless to mention that this technical collaboration has led to the growth of industries like automobile, pharmaceutical, software, electronic industries etc. in India.

\section{FDI policies in India in the pre-reform period}

After attaining independence, the main objective of the policy makers was to achieve a 'self reliant' economy. Hence emphasis was laid on developing industries, largely in public sector. Utilization of mineral resources was needed for rapid growth of the industries. Government of India did not allow private and foreign enterprises in the extraction of natural resources. The public sector enterprises were given the absolute monopoly in extracting the natural resources of the country. FDI in agriculture was discouraged because it provides livelihood to the majority of the people in the country and any foreign investment in this sector could create disturbances in the agricultural production set-up and also undue competition to Indian farmers. Hence, FDI in the agricultural sector (except for plantation of tea and coffee, which were largely commercial) was not encouraged.

FDI in manufacturing was allowed to bring the latest technology in the country. In the pre-reform period the inflow of FDI in the manufacturing sector increased from a mere 27.8 percent in 1948 to 84 percent in 1980, however, since then, the FDI inflow in the manufacturing sector has started to decline. The industries which attracted bulk of FDI in the manufacturing sector are food and 
beverages in the early 1950s, chemicals and pharmaceuticals and metal and machinery in the 1980s and transport and machine equipments in the 1990s.

In the pre-reform period, majority of FDI in India took place in the primary and manufacturing sector. However, with the growth of the economy, the share of FDI in the primary sector declined whereas the share of FDI in the manufacturing sector increased substantially. FDI inflow in the primary sector took place in tea plantation, mining and petroleum industries. The tea and the petroleum industries have been started by foreign Companies (particularly English Companies) and their impact continued even after India achieved its independence. However, it was not possible to remove the foreign companies from these sectors abruptly.

Table 2. Sector-wise/Industry-wise flow of FDI in the pre-reform period (in percentage)

\begin{tabular}{|l|l|l|l|l|l|}
\hline Industry/Sector & $\mathbf{1 9 4 8}$ & $\mathbf{1 9 6 0}$ & $\mathbf{1 9 7 0}$ & $\mathbf{1 9 8 0}$ & $\mathbf{1 9 9 0}$ \\
\hline Plantations & 20.4 & 19 & 16.5 & 4.1 & 9.46 \\
\hline Mining & 4.5 & 2.4 & 0.8 & 0.9 & 0.30 \\
\hline Petroleum & 8.7 & 29.7 & 16.7 & 4.0 & 0.11 \\
\hline 1. Primary Sector & $\mathbf{3 3 . 6}$ & $\mathbf{5 1}$ & $\mathbf{3 4}$ & $\mathbf{9}$ & $\mathbf{1 1 . 1}$ \\
\hline Food \& beverages & 14.2 & 6.4 & 5.6 & 4.2 & 4.9 \\
\hline Textiles & 39.4 & 2.7 & 3.0 & 3.5 & 2.9 \\
\hline Transport equipment & 1.4 & 1.2 & 3.7 & 5.6 & 12.4 \\
\hline Machinery and machine tools & 1.7 & 0.8 & 3.8 & 7.6 & 12.6 \\
\hline Metal \& metal Products & 11.3 & 2.8 & 8.8 & 12.7 & 5.1 \\
\hline Electrical goods & 6.8 & 2.3 & 6.5 & 10.5 & 11.0 \\
\hline Chemicals \& pharmaceuticals & 3.1 & 6.4 & 18.8 & 32.4 & 28.0 \\
\hline Miscellaneous & 9.9 & 6.2 & 12.0 & 10.7 & 6.4 \\
\hline 2. Manufacturing & $\mathbf{2 7 . 8}$ & $\mathbf{3 0}$ & $\mathbf{6 0}$ & $\mathbf{8 7}$ & $\mathbf{8 3 . 2}$ \\
\hline Trading & 16.3 & 5.4 & 2.6 & 2.3 & 0.92 \\
\hline Construction, utilities transport & 11.9 & 7.6 & 1.6 & 0.6 & 1.74 \\
\hline 3. Services & $\mathbf{3 8 . 7}$ & $\mathbf{1 9 . 5}$ & $\mathbf{1 6 . 0}$ & $\mathbf{4 . 0}$ & $\mathbf{5 . 1 8}$ \\
\hline Total FDI (current Rs. crores) & $\mathbf{2 5 5 . 8}$ & $\mathbf{5 0 1 . 7}$ & $\mathbf{7 3 5 . 4}$ & $\mathbf{9 3 3 . 0}$ & $\mathbf{2 7 0 5 . 0}$ \\
\hline & & & & & \\
\hline
\end{tabular}

Source: Bhati (2006)

Moreover, these Companies were responsible for distribution and export of tea in different countries of the world. Hence, after achieving independence, there was an attempt from the 
government of India, to reduce the dominance of foreign companies from tea plantation. Similarly, in the case of petroleum industry, phase wise reduction of the shares of foreign companies from India was undertaken. As a result, the share of petroleum towards total FDI inflow in the country started declining.

\section{Sectoral Distribution of FDI Inflow in India after Economic Reform of 1991}

The liberalization of the Indian economy took place in June, 1991. A number of reform measures were introduced to remove restrictions regulating the inflow of FDI in India. The Industrial Policy Resolution (IPR) of 1991 made departure from the earlier industrial policies and introduced three major changes. Of these, the first two changes were introduced with regard to domestic industries and the third with regard to the foreign investment policy. The IPR of 1991 allowed 51 percent foreign equity and foreign technology agreements for 34 industries (IPR, 1991). One of the policy measures was the gradual removal of licensing and allowing FDI in many sectors in India, erstwhile only reserved for Indian companies (IPR, 1991) (Handbook, 2000-01). Another important reform was the opening up of most of the sectors to the outside world, previously reserved only for the Indian companies. According to the New Industrial Policy, almost all the sectors were open for the foreign companies except five sectors, namely - retail trading, atomic energy, lottery business, housing, and real estate and agriculture, except tea plantation (Economic Survey, 1996-97).

The foreign investment inflow in the post-reform period shows two diverse trends in two decades. Hence, I have divided the sectoral distribution of FDI inflow into following divisions:

i) Manufacturing sector dominating FDI inflow during 1990 to 1999

ii) Service sector dominating FDI inflow since January 2000 till date. 


\section{i) Sector-wise FDI inflow during August 1991 to December 1999}

FDI policy in the 1990s gradually opened up most of the sectors and raised the sectoral limit in others. FDI policy in the mid-1990s was more in favour of manufacturing sector, while being more conservative in service sector. Further, there was discrimination between Foreign Investors (FIs)/Foreign Institutional Investors (FIIs) and Non Resident Indians (NRIs)/Person of India Origin (PIOs)/Overseas Corporate Bodies (OCBs), as sectoral limit was higher in case of NRIs and PIOs in some of the sectors.

By late 1990s the sectoral limit was raised in some of the industries. In addition to 34 priority industries where 51 percent equity was allowed under automatic approval, nine more high priority industries in metallurgical and infrastructures sector were opened for both FIIs and PIOs/NRIs/OCBs with FDI limit up to 51 percent foreign equity. Foreign investment up to 100 percent was allowed in the power sector. Again, 100 percent equity repatriable under automatic approval was allowed in the Export Oriented Units EPZ, Software and Hardware Technology Parks. In drug and pharmaceuticals, foreign investment limit was increased to 61 percent in case of bulk drugs (Economic Survey, 1995-96).

Though IPR of 1991 did not address the issues related to foreign investment in service sector, however, with change in time, foreign investment policy in the country was broadened to include service sector. By late 1990s, foreign investment in service sectors like banking and non-banking financial services, hotel and tourism, telecommunication etc. were also opened. In the banking services, foreign investment up to 20 percent was allowed for FIIs/FIs and foreign investment up to 40 percent was allowed for NRIs/OCBs/PIOs. In the case of Non Banking Financial Companies (NBFCs), investment up to 51 percent with no conditions and 100 percent with conditions was allowed for both FIIs and PIOs/NRIs/OCBs. In case of telecommunication, FDI up to 49 percent was allowed in basic cellular mobile and paging while in the housing and real estate, business centre and infrastructural facilities, only NRIS/PIOs/OCBs were allowed 100 percent equity on repatriation basis. 
From the above guidelines for foreign investment limit, it is clear that in the 1990s, FDI in the manufacturing sector was encouraged while FDI in the service sector was restricted. Perhaps, this was the reason why most of the FDI inflow during 1991-1999, was concentrated in the manufacturing sector with inflow of FDI in the service sector. Table 3 shows the sector-wise distribution of FDI inflows in India during 1991-1999. The liberalization policy undertaken by the Government of India yielded the return, as most of the manufacturing sector registered higher inflow of FDI. The sectors which attracted higher inflow of FDI during the first decade of economic reforms were transportation industry which includes automobile industry, air and sea transport, passenger car, ports and railway related components. It received 9 percent of the total FDI inflow in the country during 1991-1999. Electric equipment (including computer software, electrical equipment, electronics and computer hardware) received about 8 percent of the total FDI in the country in the same period.

Table 3. Sector-wise break-up of FDI inflow in India (August 1991December 1999)

\begin{tabular}{|l|r|r|}
\hline Industry/ sector & $\begin{array}{l}\text { Cumulative } \\
\text { FDI Inflow (Rs. Crore) }\end{array}$ & \multicolumn{1}{l|}{$\begin{array}{l}\text { Percentage of } \\
\text { FDI Inflow }\end{array}$} \\
\hline 1. Primary sector & - & - \\
\hline Transportation Industry & 5152.1 & 8.93 \\
\hline $\begin{array}{l}\text { Electrical equipment } \\
\text { (inc. Software and Electronic }\end{array}$ & 4642.5 & 8.05 \\
\hline Chemicals(except Fertilizers) & 3986.2 & 6.91 \\
\hline Fuels(power and refinery) & 3643.4 & 6.32 \\
\hline Food processing industries & 2367.7 & 4.10 \\
\hline Drugs and pharmaceuticals & 822.2 & 1.43 \\
\hline Metallurgical industries & 633.3 & 1.10 \\
\hline 2. Manufacturing & $\mathbf{3 4 9 8 6 . 6}$ & $\mathbf{6 1 . 1 3}$ \\
\hline Telecommunications & 4037.7 & 7 \\
\hline Service sector & 4044.9 & 6.3 \\
\hline Consultancy services & 22.0 .0 & 0.04 \\
\hline Trading & 671.4 & 1.16 \\
\hline Hotel and tourism & 304.3 & 0.53 \\
\hline 3. Services & $\mathbf{9 0 7 2 . 2}$ & $\mathbf{1 5 . 2 5}$ \\
\hline 4. Unspecified & $\mathbf{1 6 0 2 2 . 5}$ & $\mathbf{2 3 . 6 2}$ \\
\hline Total FDI & $\mathbf{5 7 6 8 2 . 1}$ & $\mathbf{1 0 0}$ \\
\hline
\end{tabular}

Source: SIA Newsletter, January 2005. DIPP (Newsletter, 2005). 
The sectoral composition of FDI inflow in India during 1991-99 has undergone a significant change. Since 1980s, FDI inflow concentrated mainly in the manufacturing sector. Among the manufacturing sub-sectors, FDI was distributed in food and beverages, transport equipment, metal and metal products and electronics, chemicals and allied products and miscellaneous manufacturing. The liberalized regime also brought about positive impacts on the service sector, which are discussed below.

\section{ii) Sector-wise FDI inflow during January 2000 to December 2010}

By early 2000s, the sector-wise inflow of FDI in India shifted towards service sector as more and more sectors were opened for the foreign investors and in case of existing sectors foreign investment limit was raised. In the second decade of economic reforms, foreign investment has been extended to the services sector and in case of manufacturing sector the foreign investment limit was increased to 100 percent in most of the manufacturing industries. By 2008, the lists of industries reserved for public sector were reduced from six in 1991 to only two, viz. railways transport and atomic energy. Those industries for which industrial licensing are compulsory were also reduced to five. (Handbook, 2008-09).

FDI policy in India has been subject to periodic changes. Now, 100 percent foreign investment is allowed in most of the manufacturing industries like alcohol-distillation and brewing, coffee and rubber processing and warehousing, hazardous chemicals, industrial explosives, drugs and pharmaceuticals power (including generation transmission, distribution and trading) and manufacture of telecom equipments under RBI automatic approval route. Again, 100 percent FDI in manufacturing is also granted under FIPB route in cigars and cigarettes petroleum and natural gas.

According to the change in FDI policy in 2008, 100 percent FDI in agriculture under RBI automatic route was allowed in floriculture, horticulture, development of seeds, animal husbandry, pisciculture and aquaculture. Major policy changes took place in the services sector. Now, almost all the services are opened for foreign investors, though sectoral limit for foreign investor differs. For instance, 100 percent FDI through RBI automatic route is allowed in 
construction activities (like housing, commercial premises, resorts, educational institutions, township etc.), non-banking finance companies (including merchant banking, financial consultancy, venture capital, rural credit, housing finance, stock broking etc.) whole sale trading, SEZ and FTZ. FDI up to 74 percent is allowed in banking (private sector).

Table 4. Sectors attracting highest FDI inflows during January 2000 - December 2010

\begin{tabular}{|c|c|c|}
\hline Industry/ Sector & $\begin{array}{l}\text { Cumulative FDI } \\
\text { Inflows (Rs. Crore) }\end{array}$ & Percentage \\
\hline 1.Primary Sector(Mining) & 3381.4 & 0.60 \\
\hline Automobile Industries & 26302.5 & 4.64 \\
\hline Power & 25879.3 & 4.57 \\
\hline Metallurgical industries & 17959.9 & 3.17 \\
\hline Petroleum and Natural Gas & 13585.9 & 2.40 \\
\hline $\begin{array}{l}\text { Chemicals (Other than } \\
\text { Fertilizers) }\end{array}$ & 12925.9 & 2.28 \\
\hline 2. Manufacturing & 171290.4 & 30.21 \\
\hline Services Sector & 118405.3 & 20.89 \\
\hline $\begin{array}{l}\text { Computer Software and } \\
\text { Hardware }\end{array}$ & 47274.4 & 8.34 \\
\hline Telecommunication & 46737.7 & 8.25 \\
\hline $\begin{array}{l}\text { Housing and Real Estate } \\
\text { (including Cineplex, Multiplex, } \\
\text { integrated Townships and } \\
\text { Commercial complexes etc.) }\end{array}$ & 420517.3 & 7.42 \\
\hline Construction Activities & 39801.9 & 7.02 \\
\hline Trading & 11713.6 & 2.07 \\
\hline Hotel and Tourism & 10304.9 & 1.82 \\
\hline 3. Services & 362422.1 & 63.93 \\
\hline 4. Unspecified & 31094.2 & 5.4 \\
\hline Total & 568835.3 & 100 \\
\hline
\end{tabular}

Source: SIA, Newsletter, Annual Issue, 2010-11, DIPP. (Newsletter, 2010-11).

Table 5 shows the inflow of FDI in different sectors during 2000 to 2010. The change in FDI policies has also brought drastic change in the composition of sector-wise inflow of FDI in the country. First, there is reversal of trend of FDI inflow. During this period manufacturing sector lost its dominance in terms of attracting FDI 
inflow in the country. The share of manufacturing in total FDI inflow reduced from 61.13 percent during 1991-1999 to 30.21 percent during 2000-2010. While in the same period the share of services sector in India has increased from mere 15.25 percent to 63.9 percent. This increase in services share may be due to changes in FDI policies mentioned above and also due to the change in the composition of world's inward FDI (refer Table 5.1).

The analysis of FDI inflow in the service sector reveals that about 64 percent of FDI inflow has taken place in the service sector. The sub-sectors that attracted the major FDI inflow are services, which includes financial and non-financial (21 percent), computer software and hardware (9 percent), telecommunication (8 percent), housing and real estate (8 percent), construction activities (7 percent), etc. The manufacturing sector which attracted majority of FDI in the 1990s failed to keep its momentum, and its share towards sectoral inflow gradually declined. None of the manufacturing activities figures in the top five sub-sectors.

A critical review of the FDI policy and the sectoral limit on FDI reveals that FDI limit in most of the manufacturing sector is 100 percent under automatic approval, but these sectors failed to attract proportionate investment. Despite Government's pro-active FDI policy, the manufacturing sector in India failed to reap the benefits. On the other hand, service sector highly benefitted from the liberalization measures. FDI in services sector led to the growth of new industries such as telecommunication, Information Technology (IT), Business Processing Outsourcing (BPO) in the country. It created huge job opportunities in the metropolitan cities of the country. These sectors employ professionally qualified labour force of the country.

There are a number of plausible reasons for scanty inflow of FDI in the manufacturing sector of India since the late 1990s. Firstly, the demand for Indian manufacturing is still limited by the size of the domestic market. Therefore, its growth is limited by the extent of home market. For increasing production to meet export demand, there has to be substantial productivity improvement (Sach and Warner, 1995). Secondly, the manufacturing sector growth in the post-reform India is 'input driven' rather than efficiency driven. The material cost of production in the manufacturing industries is 
higher when compared with its competitors in the global market. The UNIDO report of 2002 provides evidence for the stagnation of India's competitiveness, while showing that China has sharply improved its global ranking in the industrial sector competitiveness. Thirdly, India's share in the world's export of skill-intensive products is substantially lower than that of China. Though India and China are labour-surplus economies, India enjoys comparative advantage in labour-intensive manufactured products while China has been diversifying into the production of differentiated and skill-intensive products (Tendulkar, 1999).

Fourthly, the economic growth in India is enclave in nature with certain industrial belts in the country. For example, there are a number of major industrial zones within India like Delhi-Noida industrial region, Ahmedabad-Vadodra industrial region, MumbaiPune industrial region, Bangalore-Coimbatore industrial region, Chottanagpur industrial region and Hooghly industrial belt. Apart from these, there are minor industrial regions developed in Chennai, Kanpur, Indore, Godavari -Krishna belt, etc.

Most of these regions have been growing in isolation due to poor connectivity. The manufacturing sector requires good means of transportation for easy movement of raw materials as well as rapid movement of the finished products. The transportation and communication facilities within India are still underdeveloped. Hence, the cost of transportation via road and rail is comparatively higher. Further, waterways and port facility is not well developed to connect these regions of the country.

All these factors make investment in manufacturing sector in India non-competitive. Moreover, the growth of services sector is not limited by the development of physical infrastructure among the regions. Most of the service sectors like finance, non-banking financial services, health care, education and software industries could easily develop in enclave industrial and urban structures without any huge investment on infrastructure. Perhaps, this market-driven uneven and enclave nature of growth is compatible with the growth of the services sector which is evident from the Indian experience. 


\section{FDI and the Growth of New Services in India}

The second decade of economic reforms witnessed the growth of new services in the country. This was due to the persistent liberalization measures adopted by the Government of India. One of the big changes that took place during the second decade of economic reforms is the shift of FDI inflow in the country from manufacturing to services. The change in liberalization policy reflected in the rapid growth of FDI inflow in new services such as computer software and hardware, financial and non-financial services, housing and real estate and construction activities.

\section{Services Sector}

Service sector has been receiving the highest FDI inflow in the country in the second decade of economic reform. Service sector comprises of financial and banking services, insurance, business services, outsourcing, research \& development (R\&D), courier etc. Cumulative FDI inflow in the service sector was Rs. 118405.3 crores during January 2000 to December 2010. Most of the FDI in services sector went to Maharashtra (60 percent), followed by New Delhi (12 percent), Karnataka (4 percent), Gujarat (2.2 percent) and Andhra Pradesh (1.9 percent). The share of these five states towards FDI in service sector is approximately 80 percent. The countries which are investing in India's service sector are Mauritius (40.63 percent), Singapore (12.2 percent), United Kingdom (9.83), United States of America (7.8 percent), and Switzerland (3.36 percent). Newsletter (2010-11).

\section{Computer Software and Hardware}

Computer software and hardware were included under electrical equipment sector until 2002. However, this sector was recognized as a single entity in 2003. This sector includes computer software industry, computer hardware and other software. During January 2000 to December 2010, a cumulative FDI inflow in this sector is Rs. 47274.1 crores. The computer software received the highest amount of FDI during January 2000 to December 2010. The share of computer software industry was 8.98 of the total FDI inflow during the same period while the share of computer hardware was only 0.08 percent of total FDI inflow. Most of the FDI in this sector came from Mauritius (50.81 percent) followed by United States (12.57 
percent), and Singapore (9.81 percent), Netherlands (6.48 percent) and United Kingdom invested only 2.25 of the total investment in this sector. (Newsletter, 2010-11).

\section{Telecommunication}

Another important sector which owes its growth to economic reforms in the early 1990s is the telecommunication industry. Telecommunication industry includes telecommunication, radio paging, cellular mobile/basic telephone services and others (telecom). The cumulative FDI equity inflow received during January 2000 and December 2010 was Rs. 46553.0 crores which consisted of 8.05 percent of the total FDI inflow in the country. Most of these FDI had gone into the states of Delhi, Mumbai, Ahmadabad, Chennai and Bangalore (Newsletter, 2010-11).

\section{Housing and Real Estate}

This is a new sector which attracted lot of FDI in the second decade of economic reform. Previously, FDI in this sector was only allowed for the Non Resident Indian/OCBs. As a result FDI inflow in this sector was very low during the period August 1991 to December 1999. However with change in FDI policy, 100 percent equity participation is allowed through the RBI's automatic route ${ }^{1}$. The change in policy resulted in high flow of FDI in this sector after 2006. FDI inflow in this sector is allowed in housing and real estate (including Cineplex, multiplex, integrated township and commercial complexes). FDI in this sector came from the investor of Mauritius (65.7 percent) followed by Cyprus (12.36) and Netherlands 4.80 percent. As far as the destination of FDI in this sector is concerned, it is confined to the states of Maharashtra (38 percent) and New Delhi (33 percent) (Newsletter, 2010-11).

\section{Construction Activities}

Construction activities sector includes road and highways, warehouses and construction. 100 percent FDI in roadways and highways was allowed since economic reform. But inflow of FDI in road and highways was very low till 2004. But after 2004 this sector received rapid growth of FDI. The cumulative FDI inflow in this

1 Press Notice No. 2 (2005 Series) 
sector during January 2000 to December 2010 was Rs. 37702.5 crores and the share of this sector was about 6.65 percent of the total FDI inflow in the country. The region of New Delhi received the maximum of 32 percent of total FDI in this sector followed by Mumbai which has received 25 percent of the total FDI inflow in the country (Newsletter, 2010-11).

\section{FDI and Export of Services}

FDI in a country is highly appreciable if it is export promoting and most of the developing countries encourage it. India has experienced two decades of foreign investment. In the first decade it was manufacturing sector which attracted the bulk of FDI in the country. Most of the developing countries are opening their economies for the foreign investor to encourage exports from their country. But, India failed to achieve this objective in the first decade. However with liberalization of the service sector in India, this sector attracted bulk of FDI during 2000-2010 which resulted into the growth of services export from India. Table 5.5 shows the total export of services during 2000-01 to 2009-2010.

Service exports in India is divided into five broad categories, namely travel, transportation, insurance, GNIE2 ${ }^{2}$ and miscellaneous items (which includes software services, business services, financial services and communication services). Service export in India is included in the Balance of Payment table under current account invisible transaction category. Prior to 2000-01, software, business, financial and communication services were calculated together under miscellaneous services category. But from 2000-01 separate calculation for each of the services is reported in the Balance of Payment statement. The share of miscellaneous services towards total export services was $43.6^{3}$ percent in 1991-92. However with rapid increase in software exports in the country, share of miscellaneous export towards total service export increased to $60^{4}$ percent in 2000-01.

\footnotetext{
2 Government Not Included Elsewhere

'Source: Compiled by the researcher using data from India's overall Balance of Payment. Handbook of Statistics on Indian Economy, RBI, GOI.

4 Source: same as footnote 1
} 
Table 5 Services Exports from India

(Rs. crore)

\begin{tabular}{|l|c|c|c|c|c|}
\hline Year & $\begin{array}{c}\text { Total } \\
\text { Service }\end{array}$ & $\begin{array}{c}\text { Software } \\
\text { services }\end{array}$ & $\begin{array}{c}\text { Business } \\
\text { Services }\end{array}$ & $\begin{array}{c}\text { Financial } \\
\text { services }\end{array}$ & $\begin{array}{c}\text { Communication } \\
\text { services }\end{array}$ \\
\hline $2000-01$ & 74555 & 29013 & - & - & - \\
\hline $2001-02$ & 81739 & 36038 & - & - & - \\
\hline $2002-03$ & 100419 & 46424 & - & -- & - \\
\hline $2003-04$ & 123175 & 58781 & - & - & - \\
\hline $2004-05$ & 193711 & 79404 & 23067 & 2279 & 6191 \\
\hline $2005-06$ & 255668 & 104632 & 41356 & 5355 & 7000 \\
\hline $2006-07$ & 333093 & 141356 & 65738 & 14010 & 10227 \\
\hline $2007-08$ & 363042 & 162020 & 67430 & 12917 & 9682 \\
\hline $2008-09$ & 467915 & 212242 & 75632 & 18060 & 9903 \\
\hline $2009-10$ & 443881 & 235162 & 55041 & 17716 & 5859 \\
\hline
\end{tabular}

Source: Handbook of Statistics on Indian Economy, Reserve Bank of India (2012).

After the liberalization of the Indian economy, the inflow of foreign direct investment in the country started increasing in the service sector. As a result the export of business services also started increasing at a rapid rate. Business service includes Information Technology (IT), Information Technology Enabled Services (ITeS).

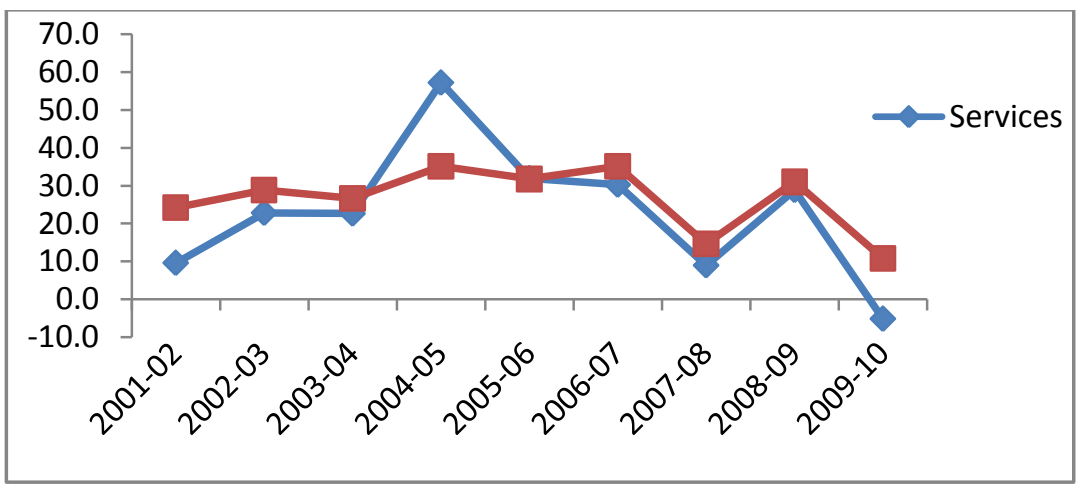

Fig 1 Growth rate of Service Export and Software Export

Source: Compiled by the researcher, Handbook of Statistics on Indian Economy, RBI

The IT-ITeS industry has four major sub-components: IT services, business process outsourcing (BPO), engineering services and research and development (R\&D), and software products. As per 
the estimates of NASSCOM, India's IT and BPO sector (excluding hardware) revenue was US\$ 87.6 billion in 2011-12, generating direct employment for nearly 2.8 million persons and indirect employment of around 8.9 million. As a proportion of national GDP, IT and ITeS sector revenues have grown from 1.2 per cent in 1997-8 to an estimated 7.5 per cent in 2011-12. (Reserve Bank, 2012).

Figure 1, shows the growth rate of total services export vis-à-vis software export. The growth rate of software services is always higher than growth rate of services (except for the year 2004-05). In other word software growth in the economy had propelled the service export in India since 2000-01.

\section{Findings and Conclusion}

On the basis of the descriptive statistics cited above we find that there is a gradual shift in the movement of FDI inflow in the world. At present most of the movement of FDI in the world is taking place in the services sector, followed by manufacturing and primary sectors. In the last two decades, though the share of manufacturing in the world declined, it has increased in the developing economies.

- FDI in the primary sector declined in the post reform period. Globally, FDI in the primary sector mainly takes place in the exploration of natural resources. In the case of India, however, FDI in this sector has declined, as our FDI policy does not permit extraction of natural resources.

- FDI inflow in India has led to the growth of new sectors such as IT and ITES in India. Majority of FDI in the last decade is taking place in this sector.

- Manufacturing sector in India has failed to attract the desired quantum of FDI.

- Export from services in India has increased, but we do not find the growth of export from manufacturing sector.

- Change in FDI policy has favoured the growth of new services like services (financial and non-financial), telecommunication, computer software and hardware, hotel 
and tourism, construction activities and real estate in the post reform period in India.

The sector specific policy guidelines play an important role in the determination of FDI inflow in India. The rapid inflow of FDI in the service is a testimony of the fact that FDI can play important role in the growth of different industries and sector. Manufacturing sector in India could not reap the benefit of FDI may be because India lacks the necessary absorbing capacity. Though, the role of FDI in India's economic growth cannot be ruled out, but it failed to create growth in the manufacturing sector, where it was needed most. Moreover, a strong manufacturing sector is of utmost importance for the sustainable growth of service sector. If Indian economy wants to maintain sustainable service led growth, then it must have a vibrant manufacturing sector, which is only possible by attracting more and more FDI in the manufacturing sector. Moreover, the rapid growth of new services in India may be attributed to the global FDI inflow in the services sector. This kind of growth which is propelled by the global economic environment is vulnerable to global economic phenomena and is not conducive to a developing country like India. A recession in any part of the world would have its impact on the Indian economy as well. So this kind of growth dictated by the developed countries will have long term repercussion. But if the manufacturing sector is developed than the host economy is less susceptible to global economic slowdown and more insulated to external disruptions.

\section{References}

Bhati, U. (2006). Foreign Direct Investment: Contemporary Issues, Deep \& Deep Publications Pvt. Ltd., New Delhi.

Economic Survey (1995-96). Ministry of Finance, Government of India, New Delhi.

Handbook of Industrial Policy and Statistics (2000-01). Department of Industrial Policy and Promotion, Ministry of Commerce and Industry, Government of India, New Delhi.

Handbook of Industrial Policy and Statistics (2008-09). Department of Industrial Policy and Promotion, Ministry of Commerce and Industry, Government of India, New Delhi.

Newsletter (2005). January Issue, Department of Industrial Promotion and Policy, Government of India. 
Newsletter (2010-11). Annual Issue, Department of Industrial Promotion and Policy, Government of India.

Reserve Bank of India (2012). Handbook of Statistics on Indian Economy, New Delhi.

Sachs, J. D. \& Warner, A. (1995), 'Economic reform and the Process of Globalization", Brookings Paper on Economic Activity, 1,1-95, Retrieved from http:/ /links.jstor.org/sici?sici=00072303\%281995\%291995\%3A1\%3C1\%3AERATPO\%3E2.0.C0\%3B2-G, accessed on 2103/2013.

Tendulkar, S. D. (1999). Exports in India's Growth Process. Indian Council of Research on International Economic Relations. Working Paper Number 46, New Delhi, Retrieved from http;//www.icrier.res.inpublic/46.html on 21/06/3 2013. 